\title{
Pembentukan Self Help Group Keluarga Orang Dengan Ngangguan Jiwa (ODGJ)
}

\author{
Efri Widianti, Taty Hernawaty, Titin Sutini, Aat Sriati, Nur Oktavia Hidayati, Imas Rafiyah \\ Departemen Keperawatan Jiwa Fakultas Keperawatan Unpad \\ Email: efri.widianti@unpad.ac.id
}

\begin{abstract}
Abstrak
Kondisi yang dialami oleh klien gangguan jiwa seringkali menyebabkan ketakutan dan kecemasan pada keluarga dan masyarakat sehingga diperlukan suatu upaya untuk bisa membantu keluarga beradaptasi dengan proses perawatan keluarganya yang mengalami gangguan jiwa. Proses adaptasi keluarga lebih cepat diwujudkan ketika keluarga dengan masalah yang sama berkumpul dan sharing untuk mengatasi masalah yang sama dalam sebuah kelompok swabantu yang disebut self help group. Tujuan dari kegiatan pengabdian kepada masyarakat ini adalah untuk memfasilitasi pembentukan self help groups keluarga klien gangguan jiwa di wilayah kerja puskesmas Sukamerang Kabupaten Garut. Tahapan dalam kegiatan terdiri dari sosialisasi kegiatan nersama tokoh masyarakat setempat, pelatihan kader kesehatan, psikoedukasi keluarga, terapi suportif keluarga, dan proses pembentukan self help group. Metode pelaksanaan kegiatan pengabdian pada masyarakat ini adalah psikoterapi kelompok (group therapy) yang dimana dalam kelompok tersebut dilaksanakan diskusi, sharing experience, role play, dan tanya jawab. Luaran yang akan dihasilkan dalam kegiatan pengabdian kepada masyarakat ini adalah terbentuknya self help group atau kelompok swabantu pada keluarga klien dengan gangguan jiwa. Kesimpulan dari kegiatan ini adalah self help group yang terbentuk pada keluarga klien dengan gangguan jiwa merupakan suatu cara untuk menurunkan dampak psikososial pada keluarga dalam perawatan klien gangguan jiwa dan meningkatkan adaptasi dan produktifitas keluarga dalam merawat klien gangguan jiwa di rumah
\end{abstract}

Keywords: Gangguan jiwa, kelompok swabantu,keluarga, self help group. 


\section{Pendahuluan}

Jumlah penderita gangguan jiwa dari tahun ke tahun mengalami peningkatan. WHO (2009) memperkirakan 450 juta orang di seluruh dunia mengalami gangguan mental, sekitar $10 \%$ adalah orang dewasa dan $25 \%$ penduduk diperkirakan akan mengalami gangguan jiwa pada usia tertentu selama hidupnya. Gangguan jiwa mencapai $13 \%$ dari penyakit secara keseluruhan dan kemungkinan akan berkembang menjadi 25\% di tahun 2030. Menurut National Institute of Mental Health (NIMH) berdasarkan hasil sensus penduduk Amerika Serikat tahun 2004, di perkirakan 26,2 \% penduduk yang berusia 18 tahun atau lebih mengalami gangguan jiwa (NIMH, 2011). Kondisi ini tidak jauh berbeda dengan kasus gangguan jiwa yang ada di negara-negara berkembang.

Indonesia merupakan salah satu negara berkembang dengan jumlah penderita gangguan jiwa yang cukup besar. Data hasil riset kesehatan dasar tahun 2013 (Depkes, 2013) yang dilakukan oleh Badan Penelitian Pengembangan Kesehatan Departemen Kesehatan, menunjukkan prevalensi gangguan jiwa di Indonesia sebesar 1.6 permil, artinya dari 1000 penduduk Indonesia, maka satu sampai dua orang diantaranya menderita gangguan jiwa. Banyaknya jumlah penderita gangguan jiwa di Indonesia ini tersebar di seluruh wilayah Indonesia, termasuk di provinsi Jawa Barat. Berdasarkan Riset Kesehatan Dasar tahun 2013 di provinsi Jawa Barat ditemukan 1,6 permil dari total penduduk jawa barat mengalami gangguan jiwa berat. Analisis pada 40 juta jiwa penduduk Jawa Barat didapatkan sekitar 64 ribu jiwa pernah mengalami gangguan jiwa berat (Depkes, 2013).

World Health Organitation (2001) menjelaskan bahwa gangguan jiwa merupakan sekumpulan gangguan pada fungsi pikir, emosi, perilaku dan sosialisasi dengan orang sekitar. Sadock dan Sadock (2010) mendefinisikan gangguan jiwa sebagai gejala yang dimanifestasikan melalui kerusakan fungsi perilaku atau psikologis yang diukur berdasarkan konsep norma dan dihubungkan dengan distress atau penyakit, tidak hanya dari respon yang diharapkan pada kejadian tertentu atau keterbatasan hubungan antara individu dan lingkungan sekitarnya. Videbeck (2013) mendefinisikan gangguan jiwa berat sebagai gejala gangguan mental berat yang menyebabkan seseorang kehilangan kemampuan untuk mengenali realitas, berhubungan dengan orang lain, dan berperilaku aneh

Peningkatan jumlah populasi penduduk dunia yang menderita gangguan jiwa menimbulkan dampak bagi keluarga dan masyarakat. Dampak yang ditimbulkan oleh gangguan jiwa dapat dibedakan menjadi dampak secara sosial dan dampak secara ekonomi. Dampak secara sosial dapat berupa pengucilan, hinaan, ejekan, dipisahkan dari lingkungan serta menimbulkan ketakutan masyarakat (Lee et al, 2005). Sedangkan dampak secara ekonomi adalah menurunnya produktivitas pasien dengan gangguan jiwa dan caregivernya, adanya beban ekonomi dan menurunnya kualitas hidup (Sadock \& Sadock, 2010). Besarnya beban yang harus ditanggung oleh keluarga, masyarakat dan negara akibat meningkatnya penderita gangguan jiwa ini perlu mendapat perhatian yang serius dengan berupaya meningkatkan pengetahuan dan pemahaman tentang gangguan jiwa dan berupaya untuk bisa mencegah dan mengatasinya. 
Efri Widianti : Pembentukan Self Help Group Keluarga Orang Dengan Ngangguan Jiwa (ODGJ)

Belum optimalnya upaya puskesmas dalam mengatasi gangguan jiwa dimasyarakat akan menyebabkan semakin kompleksnya masalah kesehatan jiwa yang ada dimasyarakat dan berdampak bukan hanya kepada individu tetapi juga keluarga dan masyarakat itu sendiri. Salah satu upaya yang dilakukan untuk mengurangi dampak tersebut adalah dengan melakukan terapi pada keluarga yang mengalami gangguan jiwa yang dikenal dengan kelompok swabantu atau self help group.

Self help group merupakan satu pendekatan untuk mempertemukan kebutuhan keluarga dan sumber penting untuk keluarga dengan gangguan jiwa (Citron, et.all, 1999 dalam Chan, 2011). Self help group merupakan suatu kelompok atau peer dimana tiap anggota saling berbagi masalah baik fisik maupun emosional atau issue tertentu (Mueser, K. T., \& Jeste, D. V, 2011). ). Self help group bertujuan untuk mengembangkan empathy diantara sesama anggota kelompok dimana sesama anggota kelompok saling memberikan penguatan untuk membentuk koping yang adaptif. Self help group pada keluarga dengan gangguan jiwa perlu dilakukan untuk membantu keluarga mengatasi permasalahannya yang diselesaikan bersama dalam kelompok.

Hasil penelitian pengaruh self help group terhadap kemampuan keluarga dalam merawat klien gangguan jiwa di kelurahan sindang barang menunjukkan Kemampuan kognitif dan psikomotor keluarga dalam merawat klien gangguan jiwa meningkat secara bermakna setelah melaksanakan self help group (Utami, 2008). Bila dilihat dari hasil tersebut self help group sangat penting dilakukan pada keluarga yang memiliki anggota keluarga yang mengalami gangguan jiwa.

Berdasarkan hasil studi pendahuluan terdapat 116 klien yang mengalami gangguan kejiwaan dan tersebar di 5 desa di kecamatan kersamanah. 116 klien tersebut terdiri dari 57 klien mengalami psikosa, 41 klien mengalami neurosa, 2 akibat napza, 41 klien dengan retardasi mental, 4 orang mengalami epilepsi dan 1 orang mengalami gangguan jiwa yang lain. Sebagian besar klien yang mengalami gangguan jiwa berada di Desa Kersamanah dan Desa Sukamaju dengan penyebaran sebagai berikut 34 klien di Desa Kersamanah dan 27 klien berada di Desa Sukamaju.

\section{Metode}

Kegiatan pengabdian masyarakat ini dilakukan dalam bentuk terapi kelompok yang beranggotakan caregiver yaitu pengambil keputusan dalam perawatan klien gangguan jiwa di rumah. Sebelum dilaksanakan pembentukan self help group, pelaksana kegiatan mengkondisikan masayarakan dan memberikan bekal pengetahuan pada keluarga dalam penanganan klien gangguan jiwa di rumah melalui kegiatan sosialisasi dan diskusi tokoh masyarakat, pelatihan kader kesehatan jiwa, psikoedukasi keluarga, terapi kelompok suportif keluarga dan baru dilanjutkan dengan pembentukan self help group keluarga dengan klien gangguan jiwa. di dalam proses terapi kelompok dilaksanakan sharing experience antar keluarga dalam merawat klien gangguan jiwa di rumah, demonstrasi, role play dan diskusi tentang cara merawat klien gangguan jiwa di rumah dan cara mengatasi dampak yang dirasakan oleh caregiver dalam perawatan klien gangguan jiwa di rumah. 
Efri Widianti : Pembentukan Self Help Group Keluarga Orang Dengan Ngangguan Jiwa (ODGJ)

Terdapat 5 kelompok swabantu yang terbentuk dalam kegiatan pengabdian pada masyarakat ini. 3 kelompok terdapat di Desa Kersamanah, 1 kelompok di Desa Sukamaju dan 1 kelompok di Desa Mekar Raya yang merupakan pemekaran dari Desa Sukamaju. Kegiatan PPM IbM ini bertujuan untuk meningkatkan kemampuan keluarga dalam merawat klien gangguan jiwa di Desa Kersamanah dan Desa Sukamaju Kecamatan Kersamanah Kabupaten Garut melalui pembentukan self help group (kelompok swabantu) keluarga dengan anggota keluarga yang mengalami gangguan jiwa.

\section{Hasil}

Terdapat beberapa tahap dalam pelaksanaan kegiatan pengabdian pada masyarakat ini, antara lain dilakukannya diskusi dengan tokoh masyarakat untuk pelaksanaan kegiatan, pelatihan kader kesehatan jiwa, psikoedukasi keluarga, terapi suportif kelompok dan pembentukan self help group (kelompok swabantu). Berikut adalah beberapa kegiatan yang telah dilaksanakan :

\section{Diskusi dan pemaparan program pengabdian pada masyarakat}

Kegiatan pemaparan program ini dilaksanakan oleh pelaksana kegiatan pengabdian pada masyarakat dengan tujuan untuk meningkatkan peran serta tokoh masyarakat dan pengambil kebijakan dalam pelaksanaan kegiatan sehingga diharapkan kegiatan ini menjadi berkelanjutan setelah program ini selesai. Kegiatan diskusi dengan tokoh ini dilaksanakan pada tanggal 10 Juni 2016 dan dihadiri oleh 15 orang tokoh masyarakat dan pemegang kebijakan di wilayah Desa Kersamanah dan Desa Sukamaju. Hasil yang didapatkan dalam pertemuan ini adalah tokoh masyarakat menyetujui dan mendukung seluruh pelaksanaan program kegiatan pengabdian masyarakat ini dan akan menganjurkan pada warga yang menjadi sasaran kegiatan untuk ikut serta secara optimal dalam mengikuti kegiatan

\section{Pelatihan kader kesehatan jiwa}

Pelatihan kader kesehatan jiwa pada kegiatan ini ditujukan untuk menyegarkan kembali peran kader dalam penanganan klien dengan gangguan jiwa di wilayah sekitar kader tersebut tinggal. Pelatihan kader ini dihadiri oleh 16 orang kader kesehatan jiwa, 2 orang petugas puskesmas dan 2 orang pelaksana pada tanggal 17 Juni 2016. Berdasarkan hasil dari pelatihan ini maka diakhiri dengan pembagian tugas dan peran kader dalam mendukung kegiatan pengabdian masyarakat ini. Pada pelatihan ini juga dihasilkan pembentukan kelompok swabantu (self help group) ditentukan berdasarkan kedekatan wilayah keluarga dengan gangguan jiwa sehingga memudahkan keluarga untuk dapat menjangkau tempat pelaksanaan kegiatan. 
Tabel 1. Evaluasi proses pelatihan kader kesehatan jiwa

\begin{tabular}{|c|c|c|}
\hline & $\begin{array}{l}\text { Sebelum } \\
\text { pelatihan }\end{array}$ & $\begin{array}{c}\text { Setelah } \\
\text { pelatihan }\end{array}$ \\
\hline $\begin{array}{l}\text { Pengetahuan } \\
\text { tentang peran } \\
\text { kader kesehatan } \\
\text { jiwa }\end{array}$ & $\begin{array}{l}50 \% \text { kader } \\
\text { dapat } \\
\text { menjelaskan } \\
\text { perannya dalam } \\
\text { penanggulangan } \\
\text { gangguan jiwa } \\
\text { di masyarakat }\end{array}$ & $\begin{array}{l}80 \% \text { kader } \\
\text { dapat } \\
\text { menjelaskan } \\
\text { perannya dalam } \\
\text { penanggulangan } \\
\text { gangguan jiwa } \\
\text { di masyarakat }\end{array}$ \\
\hline $\begin{array}{l}\text { Partisipasi } \\
\text { dalam } \\
\text { menggerakkan } \\
\text { warga } \\
\text { mengikuti } \\
\text { penyuluhan } \\
\text { kesehatan jiwa }\end{array}$ & $\begin{array}{l}40 \% \text { kader } \\
\text { mampu } \\
\text { menggerakkan } \\
\text { warga untuk } \\
\text { mengikuti } \\
\text { kegiatan } \\
\text { penyuluhan } \\
\text { kesehatan jiwa } \\
\text { yang } \\
\text { dilaksanakan } \\
\text { oleh puskesmas }\end{array}$ & $\begin{array}{l}90 \% \text { kader } \\
\text { berpartisipasi } \\
\text { aktif dalam } \\
\text { menggerakkan } \\
\text { warga untuk } \\
\text { mengikuti } \\
\text { kegiatan } \\
\text { penyuluhan } \\
\text { kesehatan jiwa }\end{array}$ \\
\hline $\begin{array}{l}\text { Partisipasi } \\
\text { dalam } \\
\text { kunjungan } \\
\text { keluarga } \\
\text { dengan } \\
\text { gangguan jiwa }\end{array}$ & $\begin{array}{l}20 \% \text { kader } \\
\text { melakukan } \\
\text { kunjungan } \\
\text { secara rutin ke } \\
\text { keluarga dengan } \\
\text { gangguan jiwa }\end{array}$ & $\begin{array}{l}60 \% \text { kader } \\
\text { menyatakan } \\
\text { akan membuat } \\
\text { jadwal kegiatan } \\
\text { kunjungan ke } \\
\text { keluarga } \\
\text { dengan } \\
\text { gangguan jiwa } \\
\text { terutama klien } \\
\text { yang putus obat } \\
\text { atau belu mau } \\
\text { berobat }\end{array}$ \\
\hline $\begin{array}{l}\text { Keaktifan } \\
\text { dalam } \\
\text { mengikuti rapat } \\
\text { koordinasi di } \\
\text { puskesmas }\end{array}$ & $\begin{array}{l}60 \% \text { kader } \\
\text { kesehatan jiwa } \\
\text { aktif mengikuti } \\
\text { rapat koordinasi } \\
\text { di puskesmas }\end{array}$ & $\begin{array}{l}80 \% \text { kader } \\
\text { kesehatan jiwa } \\
\text { bersedia } \\
\text { membuat } \\
\text { komitmen } \\
\text { untuk } \\
\text { mengikuti rapat } \\
\text { koordinasi di } \\
\text { puskesmas } \\
\text { seoptimal } \\
\text { mungkin }\end{array}$ \\
\hline
\end{tabular}

\section{Pelaksanaan psikoedukasi keluarga}

Kegiatan psikoedukasi keluarga dilaksanakan pada tanggal 23 Juni 2016 dan dihadiri oleh 55 keluarga klien dengan gangguan jiwa. kegiatan ini dilaksanakan di aula puskesmas Sukamerang. Dalam kegiatan ini keluarga mendapatkan materi tentang cara merawat klien gangguan jiwa di rumah dan bagaimana mengatasi stress dalam perawatan keluarga dengan gangguan jiwa serta penjelasan pelaksanaan program pengabdian pada masyarakat yaitu pembentukan self help group dan tahapan tahapan kegiatan yang akan dilaksanakan. 
Efri Widianti : Pembentukan Self Help Group Keluarga Orang Dengan Ngangguan Jiwa (ODGJ)

Hasil dari kegiatan ini adalah keluarga tampak antusias mengikuti materi demi materi dan bersemangat pula menyampaikan kondisi yang dialami selama merawat anggota keluarga yang mengalami gangguan jiwa serta keluarga bersedia untuk terlibat aktif dalam kegiatan pembentukan self help group sebagai upaya dalam penanganan anggota keluarga dengan gangguan jiwa, meringankan beban pikiran karena perawatan klien di rumah, dan menjaga motivasi dan semangat dalam merawat anggota keluarga dengan gangguan jiwa.

\section{Tabel 2. Evaluasi proses terapi psikoedukasi keluarga}

\begin{tabular}{|c|c|c|}
\hline & $\begin{array}{l}\text { Sebelum } \\
\text { pelatihan }\end{array}$ & $\begin{array}{c}\text { Setelah } \\
\text { pelatihan }\end{array}$ \\
\hline $\begin{array}{l}\text { Pengetahuan } \\
\text { tentang cara } \\
\text { merawat klien } \\
\text { di rumah }\end{array}$ & $\begin{array}{l}\text { Keluarga } \\
\text { mengungkapkan } \\
\text { mengetahui } \\
\text { secara teori cara } \\
\text { merawat klien } \\
\text { di rumah tapi } \\
\text { sulit untuk } \\
\text { melakukannya } \\
\text { karena sulitnya } \\
\text { perilaku klien }\end{array}$ & $\begin{array}{l}\text { Keluarga } \\
\text { akan } \\
\text { menerapkan } \\
\text { tips dan trik } \\
\text { cara merawat } \\
\text { klien di } \\
\text { rumah } \\
\text { terutama } \\
\text { pada klien } \\
\text { dengan } \\
\text { perilaku sulit }\end{array}$ \\
\hline $\begin{array}{l}\text { Pengetahuan } \\
\text { tentang } \\
\text { managemen } \\
\text { stress ketika } \\
\text { merawat klien } \\
\text { dirumah }\end{array}$ & $\begin{array}{l}\text { Keluarga } \\
\text { merasa tertekan } \\
\text { atas perannya } \\
\text { dalam merawat } \\
\text { klien di rumah } \\
\text { dan tidak tahu } \\
\text { tindakan apa } \\
\text { yang dilakukan } \\
\text { untuk mengatasi } \\
\text { perasaannya }\end{array}$ & $\begin{array}{l}\text { Keluarga } \\
\text { mengetahui } \\
\text { teknik-teknik } \\
\text { relaksasi } \\
\text { yang dapat } \\
\text { diterapkan di } \\
\text { rumah jika } \\
\text { merasa } \\
\text { tertekan } \\
\text { karena } \\
\text { perannya } \\
\text { dalam } \\
\text { merawat } \\
\text { klien } \\
\text { gangguan } \\
\text { jiwa }\end{array}$ \\
\hline $\begin{array}{l}\text { Pengetahuan } \\
\text { tentang } \\
\text { managemen } \\
\text { beban dalam } \\
\text { merawat klien } \\
\text { di rumah }\end{array}$ & $\begin{array}{l}\text { Keluarga } \\
\text { terutama care } \\
\text { giver merasa } \\
\text { mendapatkan } \\
\text { beban yang } \\
\text { berat karena } \\
\text { harus merawat } \\
\text { klien dengan } \\
\text { kondisi yang } \\
\text { cepat berubah }\end{array}$ & $\begin{array}{l}\text { Keluarga } \\
\text { mengetahui } \\
\text { cara } \\
\text { membagi } \\
\text { beban yang } \\
\text { dirasakan } \\
\text { dalam proses } \\
\text { perawatan } \\
\text { klien di } \\
\text { rumah }\end{array}$ \\
\hline
\end{tabular}

\section{Pelaksanaan Terapi Suportif Keluarga}

Terapi suportif keluarga dilaksanakan dalam bentuk kelompok kecil. Jumlah keluarga yang terlibat dalam pada tiap kelompok ditentukan berdasarkan kedekatan tempat tinggal keluarga. Kelompok yang dibentuk dalam terapi suportif keluarga ini nantinya akan diteruskan menjadi 
kelompok dalam self help group. Terdapat 5 kelompok dalam pelaksanaan terapi suportif keluarga. Terapi suportif keluarga dilaksanakan pada 9 Agustus 2016. Tabel berikut menjelaskan hasil evaluasi proses dalam terapi suportif kelompok.

Tabel 3. Evaluasi proses terapi suportif keluarga

\begin{tabular}{|c|c|c|}
\hline & $\begin{array}{l}\text { Sebelum } \\
\text { pelatihan }\end{array}$ & $\begin{array}{c}\text { Setelah } \\
\text { pelatihan }\end{array}$ \\
\hline $\begin{array}{l}\text { Memahami } \\
\text { pentingnya } \\
\text { dukungan orang } \\
\text { lain dalam } \\
\text { perawatan klien }\end{array}$ & $\begin{array}{l}\text { Keluarga } \\
\text { mengetahui } \\
\text { bahwa } \\
\text { merawat } \\
\text { klien } \\
\text { gangguan } \\
\text { jiwa di rumah } \\
\text { tanpa bantuan } \\
\text { orang lain } \\
\text { dirasakan } \\
\text { cukup berat }\end{array}$ & $\begin{array}{l}\text { Keluarga } \\
\text { memahami } \\
\text { bahwa perasaan } \\
\text { berat dalam } \\
\text { perawatan klien } \\
\text { gangguan jiwa } \\
\text { di rumah harus } \\
\text { di cari solusinya }\end{array}$ \\
\hline $\begin{array}{l}\text { Mengenali } \\
\text { sumber } \\
\text { dukungan yang } \\
\text { dapat digunakan } \\
\text { dalam proses } \\
\text { perawatan klien } \\
\text { dengan } \\
\text { gangguan jiwa }\end{array}$ & $\begin{array}{l}\text { Keluarga } \\
\text { belum } \\
\text { mengenali } \\
\text { semua } \\
\text { sumber } \\
\text { dukungan } \\
\text { yang dapat } \\
\text { dimanfaatkan } \\
\text { dalam } \\
\text { perawatan } \\
\text { klien }\end{array}$ & $\begin{array}{l}\text { Keluarga } \\
\text { mampu } \\
\text { mengidentifikasi } \\
\text { semua sumber } \\
\text { dukungan yang } \\
\text { dapat } \\
\text { dimanfaatkan } \\
\text { dalam } \\
\text { perawatan klien }\end{array}$ \\
\hline $\begin{array}{l}\text { Kemampuan } \\
\text { menggunakan } \\
\text { sumber } \\
\text { dukungan } \\
\text { internal }\end{array}$ & $\begin{array}{l}\text { Keluarga } \\
\text { belum } \\
\text { mampu } \\
\text { menggunakan } \\
\text { sumber } \\
\text { dukungan } \\
\text { internal } \\
\text { karena takut } \\
\text { mengganggu } \\
\text { kegiatan } \\
\text { sumber } \\
\text { dukungan } \\
\text { internal }\end{array}$ & $\begin{array}{l}\text { Keluarga } \\
\text { mampu } \\
\text { mempraktekkan } \\
\text { cara } \\
\text { berkomunikasi } \\
\text { yang baik } \\
\text { sebagai upaya } \\
\text { untuk } \\
\text { optimalisasi } \\
\text { sumber } \\
\text { dukungan } \\
\text { internal }\end{array}$ \\
\hline $\begin{array}{l}\text { Kemampuan } \\
\text { menggunakan } \\
\text { sumber } \\
\text { dukungan } \\
\text { eksternal }\end{array}$ & $\begin{array}{l}\text { Keluarga } \\
\text { belum } \\
\text { mampu } \\
\text { menggunakan } \\
\text { sumber } \\
\text { dukungan } \\
\text { eksternal } \\
\text { karena } \\
\text { khawatir } \\
\text { merepotkan } \\
\text { sumber } \\
\text { dukungan } \\
\text { eksternal } \\
\text { (tetangga, } \\
\text { tokoh }\end{array}$ & $\begin{array}{l}\text { Keluarga } \\
\text { mampu } \\
\text { mempraktekkan } \\
\text { cara } \\
\text { berkomunikasi } \\
\text { yang baik } \\
\text { sebagai upaya } \\
\text { untuk } \\
\text { optimalisasi } \\
\text { sumber } \\
\text { dukungan } \\
\text { eksternal }\end{array}$ \\
\hline
\end{tabular}


Efri Widianti : Pembentukan Self Help Group Keluarga Orang Dengan Ngangguan Jiwa (ODGJ)

masyarakat

setempat dll)

\section{Pembentukan Self Help Group Keluarga}

Pembentukan Self Help Group pada keluarga klien dengan gangguan jiwa merupakan kelanjutan dari psikoedukasi keluarga dan terapi suportif keluarga Terdapat 5 kelompok swabantu (self help group) keluarga yang terbentuk dalam kegiatan pengabdian masyarakat ini yaitu 3 kelompok di desa Kersamanah, 1 kelompok di Desa Sukamaju dan 1 kelompok di Desa Mekar Raya. Pertemuan pertama dalam kegiatan pembentukan Self Help Group ini dilaksanakan pada 28 Agustus 2016. Pembentukan self help group dilakukan dalam 2x pertemuan. Pertemuan pertama terapis memimpin jalannya terapi kelompok, menjelaskan manfaat dan cara pembentukan self help group. Pertemuan kedua, ketua kelompok terpilih memimpin jalannya pertemuan kelompok, terapis mendampingi sebagai fasilitator dan narasumber pembahasan permasalahan perawatan klien gangguan jiwa di rumah.

Tabel 4. Karakteristik keluarga peserta Self Help Group $(n=48)$

\begin{tabular}{|c|c|c|c|}
\hline \multicolumn{2}{|r|}{ Karakteristik } & $\mathrm{N}$ & $f(\%)$ \\
\hline \multicolumn{4}{|l|}{ Usia } \\
\hline & $18-25$ tahun & 2 & 4.2 \\
\hline & $25-40$ tahun & 7 & 14.6 \\
\hline & $40-60$ tahun & 30 & 62.5 \\
\hline & $>60$ tahun & 9 & 18.7 \\
\hline \multicolumn{4}{|c|}{ Jenis kelamin } \\
\hline & Laki laki & 3 & 6.25 \\
\hline & Perempuan & 45 & 93.7 \\
\hline & & & 5 \\
\hline \multicolumn{4}{|c|}{ Status pernikahan } \\
\hline & Menikah & 30 & 62.5 \\
\hline & Belum menikah & 4 & 8.3 \\
\hline & Janda/duda & 14 & 29.2 \\
\hline \multicolumn{4}{|c|}{ Riwayat pendidikan } \\
\hline & Tidak sekolah & 10 & 20.8 \\
\hline & Tamat SD & 15 & 31.2 \\
\hline & Tamat SMP & 10 & 20.8 \\
\hline & Tamat SMA & 8 & 16.7 \\
\hline & Tamat PT & 5 & 10.4 \\
\hline \multicolumn{4}{|c|}{ Jumlah klien di rumah } \\
\hline & Satu & 35 & 72.9 \\
\hline- & Lebih dari satu & 13 & 27.1 \\
\hline \multicolumn{4}{|c|}{ Riwayat pengobatan } \\
\hline & $\begin{array}{l}\text { Pernah dirawat di } \\
\text { RS }\end{array}$ & 30 & 62.5 \\
\hline & $\begin{array}{l}\text { Belum pernah } \\
\text { dirawat di RS }\end{array}$ & 18 & 37.5 \\
\hline
\end{tabular}

Berdasarkan tabel di atas diketahui bahwa keluarga peserta pembentukan self help group mempunyai karakteristik sebagian besar berusia 40-60 tahun (62.5\%), perempuan (93.75\%), menikah (62.5\%), tidak sekolah dan tamat SMP ( masing masing 20.8\%), merawat klien satu orang di dalam satu rumah (72.9\%), dan klien yang dirawat tersebut pernah menjalani perawatan di RS (62.5\%) 
Tabel 5. Nilai rata-rata pre-test dan post-test kemampuan keluarga dalam merawat klien gangguan jiwa di rumah $(n=48)$

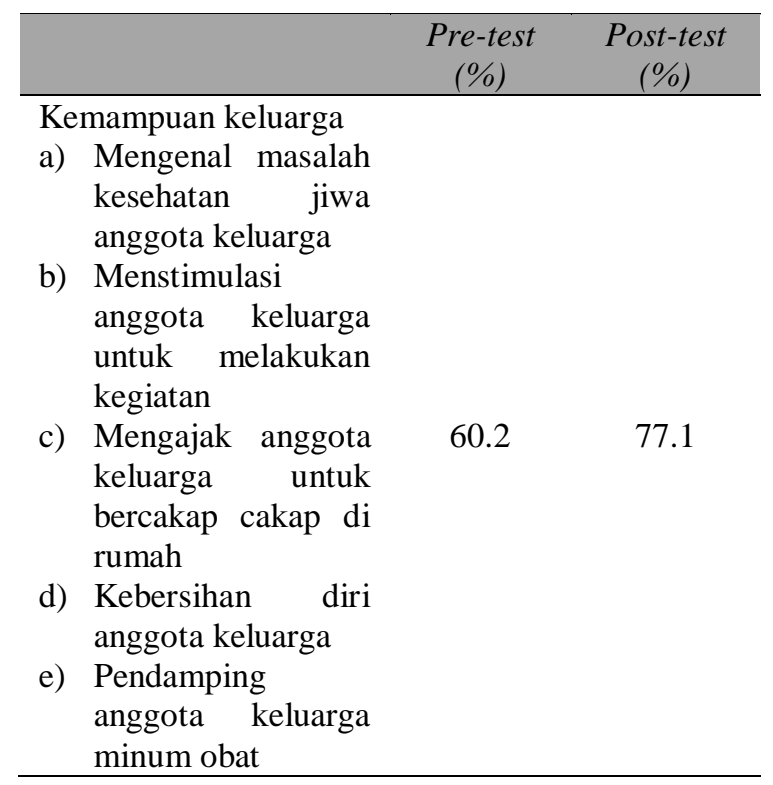

Berdasarkan nilai rata rata kemampuan keluarga dalam merawat klien di rumah sebelum dan setelah di bentuk self help group terdapat peningkatan $16.9 \%$

\section{Pembahasan}

Program SHG yang telah dilaksanakan pada kelompok masyarakat di desa Kersamanah dan desa Sukamaju membawa perubahan positif pada keluarga klien dengan gangguan jiwa. Hal ini terutama tampak dari aspek peningkatan kemampuan dan kerjasama antar keluarga yang mempunyai anggota keluarga dengan gangguan jiwa dan merawatnya di rumah. Keluarga yang tegabung dalam kelompok swabantu (self help group) ini menyatakan bahwa sebelum adanya kelompok swabantu mereka merasa berat dalam merawat klien dengan gangguan jiwa di rumah, akan tetapi setelah adanya kelompok swabantu keluarga merasa tidak sendiri lagi. Keluarga merasa bahwa ada orang lain yang juga mempunyai kondisi yang sama yaitu harus merawat klien gangguan jiwa di rumah.

Self help group merupakan satu pendekatan untuk mempertemukan kebutuhan keluarga dan sumber penting untuk keluarga dengan gangguan jiwa (Citron, et.all, 1999 dalam Chan, S.W.C, 2011) . Self help group merupakan suatu kelompok atau peer dimana saling tiap anggota berbagi masalah baik fisik maupun emosional atau issue tertentu (Chan, 2011). Self help group bertujuan untuk mengembangkan empathy diantara sesama anggota kelompok dimana sesama anggota kelompok saling memberikan penguatan untuk membentuk koping yang adaptif. Self help group pada keluarga dengan gangguan jiwa perlu dilakukan untuk membantu keluarga mengatasi permasalahannya yang diselesaikan bersama dalam kelompok.

Hasil pelaksanaan kegiatan PKM ini sejalan dengan hasil penelitian pengaruh self help group terhadap kemampuan keluarga dalam merawat klien gangguan jiwa di kelurahan sindang barang 
Efri Widianti : Pembentukan Self Help Group Keluarga Orang Dengan Ngangguan Jiwa (ODGJ)

menunjukkan Kemampuan kognitif dan psikomotor keluarga dalam merawat klien gangguan jiwa meningkat secara bermakna setelah melaksanakan self help group (Utami, 2008). Bila dilihat dari hasil tersebut self help group sangat penting dilakukan pada keluarga yang memiliki anggota keluarga dengan gangguan jiwa.

Steward (2009) menyebutkan bahwa self help group merupakan kelompok pemberi semangat karena dalam kelompok tersebut anggota kelompok membuat kesepakatan untuk salin berbagi masalah yang mereka hadapi . Self-help groups adalah suatu terapi dimana setiap anggota saling berbagi pengalaman tentang kesulitan dan cara mengatasinya, hal ini dilakukan untuk memberikan semangat kepada keluarga bahwa mereka tidak sendiri dan banyak dari mereka yang bertahan dengan kondisi seperti ini. Anggota kelompok saling berbagi nasehat, berbagi strategi koping dan saling mendukung antar anggota lainnya (Townsend \& Morgan, 2017).

Fokus dari self help group adalah perubahan sikap dan perilaku (Aglen, Hedlund \& Landstad,2011). Self help group bertujuan untuk mengembangkan empathy diantara sesama anggota kelompok dimana sesama anggota kelompok saling memberikan penguatan untuk membentuk koping yang adaptif. Self help group pada keluarga dengan anggota keluarga yang mengalami gangguan jiwa perlu dilakukan untuk membantu keluarga mengatasi permasalahannya yang diselesaikan bersama dalam kelompok.

Pembentukan kelompok swabantu (self help group) memerlukan pengkondisian terlebih dahulu. Sebelum keluarga dilatih untuk mandiri memecahkan masalahnya dan berbagi serta saling membantu dengan anggota masyarakat yang lain dan mempunyai masalah yang sama maka keluarga memerlukan bekal. Bekal tersebut diberikan kepada keluarga dalam bentuk psikoedukasi keluarga dan terapi suportif keluarga.

\section{Simpulan}

Self Help Group pada keluarga penderita gangguan jiwa merupakan suatu kelompok swabantu yang dibentuk dari masyarakat berdasarkan kebutuhan masyarakat dengan pelaksana utama masyarakat itu sendiri. Pelaksana pengabdian masyarakat dari perguruan tinggi hanya menjadi fasilitator tumbuhnya kesadaran masyarakat (keluarga penderita gangguan jiwa) untuk saling memberikan dukungan dalam mengatasi masalah yang dialami oleh keluarga

Berdasarkan hasil pelaksanaan kegiatan Pengabdian Pada Masyarakat ini, pelaksana kegiatan menyarankan untuk melakukan pendekatan secara optimal kepada para pemegang kebijakan di wilayah Kabupaten Garut sebagai upaya optimalisasi pelaksanaan kegiatan pengabdian pada masyarakat di daerah daerah lain di Kabupaten Garut (pembentukan self help group); pelaksana perlu untuk terus melakukan kajian berdasarkan hasil penelitian terbaru terkait dengan penanganan penderita gangguan jiwa di masyarakat dan mengembangkan hasil penelitian tersebut menjadi sebuah kegiatan pengabdian masyarakat yang berdaya guna berdasarkan evidence based practice 


\section{Daftar Pustaka}

Aglen, B., Hedlund, M., \& Landstad, B. J. (2011). Self-help and self-help groups for people with long-lasting health problems or mental health difficulties in a Nordic context: A review. Scandinavian journal of public health, 39(8), 813-822.

Boszormenyi-Nagy, I., \& Framo, J. L. (Eds.). (2013). Intensive family therapy: Theoretical and practical aspects. Routledge.

Caqueo-Urízar, A., \& Gutiérrez-Maldonado, J. (2006). Burden of care in families of patients with schizophrenia. Quality of Life Research, 15(4), 719-724.

Chan, S. W. C. (2011). Global perspective of burden of family caregivers for persons with schizophrenia. Archives of psychiatric nursing, 25(5), 339-349.

Davidson, L., Chinman, M., Sells, D., \& Rowe, M. (2006). Peer support among adults with serious mental illness: a report from the field. Schizophrenia bulletin, 32(3), 443-450.

Depkes RI. (2008). Riset kesehatan dasar 2007. Jakarta. Badan Penelitian dan Pengembangan Kesehatan Republik Indonesia.

Friedman, E. (2011). Generation to generation: Family process in church and synagogue. Guilford Press.

Gutiérrez-Maldonado, J., Caqueo-Urízar, A., \& Kavanagh, D. J. (2005). Burden of care and general health in families of patients with schizophrenia. Social Psychiatry and Psychiatric Epidemiology, 40(11), 899-904.

Hernawaty, T. (2009). Tesis. Pengaruh self help group terhadap kemampuan keluarga dalam merawat klien gangguan jiwa di kelurahan Sindang Barang Bogor Tahun 2008. Jakarta. Tidak dipublikasikan.

Magliano, L., Fiorillo, A., De Rosa, C., Malangone, C., \& Maj, M. (2005). Family burden in longterm diseases: a comparative study in schizophrenia vs. physical disorders. Social science \& medicine, 61(2), 313-322.

Mueser, K. T., \& Jeste, D. V. (Eds.). (2011). Clinical handbook of schizophrenia. Guilford Press.

NIMH. (2000). American psychiatric associations. http://www.nimh.nih.gov/statistics/ . diperoleh tanggal 15 Maret 2013

NIMH. (2011). Prevalence of mental ilness by disorder. http://www.nimh.nih.gov/statistics/. diperoleh tanggal 15 Maret 2013

Notoatmodjo, S. (2012). Promosi kesehatan dan perilaku kesehatan. Jakarta: Rineka cipta.

Saddock, B.J dan Saddock, V.A (2010). Kaplan and Saddock's synopsis of psychiatry: Behavioral science/clinical psychiatry. 10th Ed. Lippincott William \& Wilkins.

Steward. (2009). Self-help groups for mental health.. http://www.wikippedia.org/wiki. diperoleh tanggal 22 April 2014). 
Efri Widianti : Pembentukan Self Help Group Keluarga Orang Dengan Ngangguan Jiwa (ODGJ)

Townsend, M. C., \& Morgan, K. I. (2017). Psychiatric mental health nursing: Concepts of care in evidence-based practice. FA Davis.

Utami, T. W. (2008). Pengaruh self-help groups terhadap kemampuan keluarga dalam merawat klien gangguan jiwa di kelurahan sindang barang bogor tahun 2008. Hasil Tesis Fakultas Ilmu Keperawatan Universitas Indonesia.

Videbeck, S. L. (2013). Psychiatric mental health nursing. Second Edition, Philadelphia : Lippincott Williams \& Wilkins.

WHO. (2001). The world health report 2001, World Health Organization.

WHO. (2006). The lancet. London : Elsevier Properties SA.

WHO. (2009). Improving health system and service for mental health : WHO Library Cataloguing-inPublication Data. 